\title{
CARCINOEMBRYONIC ANTIGEN LEVELS AMONG STROKE PATIENTS
}

\begin{abstract}
Vasanthi Perumal' ${ }^{1}$ Namitha Narayanan², Raja Krishnaraj33, Thulasi Ram ${ }^{4}$, Karthikeyan ${ }^{5}$, Sindhiya Jayachandran', Pravin Selvam Selvaraj ${ }^{7}$, Shanthi Chinnathambi ${ }^{8}$
\end{abstract}

1 Professor and HOD, Department of General Medicine, Stanley Medical College and Hospital, Chennai. ${ }^{2}$ Assistant Professor, Department of General Medicine, Stanley Medical College and Hospital, Chennai. ${ }_{3}^{3}$ Assistant Professor, Department of General Medicine, Stanley Medical College and Hospital, Chennai. ${ }^{4}$ Postgraduate Student, Department of General Medicine, Stanley Medical College and Hospital, Chennai. ${ }^{5}$ Postgraduate Student, Department of General Medicine, Stanley Medical College and Hospital, Chennai. ${ }^{6}$ Postgraduate Student, Department of General Medicine, Stanley Medical College and Hospital, Chennai. ${ }^{7}$ Postgraduate Student, Department of General Medicine, Stanley Medical College and Hospital, Chennai. ${ }^{8}$ Postgraduate Student, Department of General Medicine, Stanley Medical College and Hospital, Chennai.

ABSTRACT

\section{BACKGROUND}

CEA (carcinoembryonic antigen) is mainly associated with malignant conditions, but there is a modest increase in non-malignant conditions such as aging, and atherosclerosis and this study is to find correlation of CEA levels in stroke patients.

\section{MATERIALS AND METHODS}

A case control study conducted from March 2016 to August 2016 in Stanley Medical College, General Medicine Department.

\section{RESULTS}

The mean CEA levels were significantly elevated in infarct group compared to control group by a mean difference of $5.09 \mathrm{ng} / \mathrm{mL}$ (73\% higher), which is significant with p value of 0.0001 , likewise the mean CEA levels were significantly elevated in haemorrhage group compared to control group by a mean difference of $3.26 \mathrm{ng} / \mathrm{mL}$ ( $64 \%$ higher). The CEA levels were significantly elevated in infarct group compared to haemorrhage group by a mean difference of $1.83 \mathrm{ng} / \mathrm{mL}$ ( $26 \%$ higher). This difference is significant with a p-value of 0.0071 .

\section{CONCLUSION}

The CEA levels are higher among stroke patients than normal population. The elevation is more among ischaemic stroke patients than haemorrhagic stroke patients. Infarct stroke patients had 3.73 times carcinoembryonic antigen levels compared to healthy subjects, haemorrhage stroke patients had 2.75 times carcinoembryonic antigen levels compared to healthy subjects and infarct stroke patients had 1.36 times carcinoembryonic antigen levels compared to haemorrhage stroke patients.

\section{KEYWORDS}

Stroke, CEA Levels, CRP Levels.

HOW TO CITE THIS ARTICLE: Perumal V, Narayanan N, Krishnaraj R, et al. Carcinoembryonic antigen levels among stroke patients. J. Evolution Med. Dent. Sci. 2018;7(05):653-657, DOI: 10.14260/jemds/2018/148

\section{BACKGROUND}

Stroke is a medical emergency.(1) It is the abrupt interruption of cerebral blood flow to a specific brain region resulting in neurological deficits. There are two main types of stroke-

- Ischaemic.

- Haemorrhagic.

\author{
Ischaemic Stroke can be Sub-Classified as, (2) \\ 1. Thrombosis. \\ 2. Embolism. \\ 3. Systemic hypoperfusion.
}

'Financial or Other Competing Interest': None.

Submission 18-11-2017, Peer Review 12-01-2018,

Acceptance 18-01-2018, Published 29-01-2018.

Corresponding Author:

Dr. Namitha Narayanan,

Flat No. 3, Sadhana Apartment's,

No.11, $5^{\text {th }}$ Main Road,

Nandanam Extension,

Chennai- 35.

E-mail: nami9303@gmail.com

DOI: $10.14260 /$ jemds $/ 2018 / 148$

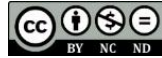

Major significant risk factors for ischaemic stroke(3) are hypertension, TIA, prior stroke, carotid artery stenosis, alcohol consumption, obesity, genetics type 2 diabetes mellitus, dyslipidaemia, cigarette smoking, OCP use and age.(1)

CEA (carcinoembryonic antigen) is mainly associated with malignant conditions, but there is a modest increase in non-malignant conditions such as aging and atherosclerosis.(4)

CEA stimulates monocytes and macrophages(5) to trigger the production of pro-inflammatory cytokines such as tumour necrosis factor- $\alpha$, nitric oxide, interleukin- $1 b$ and -6 , reactive oxygen species, eicosanoids and carbon monoxide and up-regulation of endothelial adhesion molecules and indirectly leading to atherosclerosis.(6) Further atherosclerosis increases CEA levels.

CEA has also been implicated as a marker in ischaemic stroke in various studies.

\section{Aims and Objectives}

1. To compare the levels of human carcinoembryonic antigen (CEA) in patients of acute stroke (ischaemic and Haemorrhagic) with normal population. 
2. To compare CEA with hsCRP, which is a proven marker for atherosclerosis.

\section{MATERIALS AND METHODS \\ Study Design}

Case control study.

\section{Study Period}

March 2016 to August 2016.

\section{Clinically}

Focal neurological deficit persisting $>24$ hours.

\section{Inclusion Criteria}

Patients of ischaemic and haemorrhagic stroke $>40$ years.

\section{Exclusion Criteria}

$\mathrm{K} / \mathrm{C} / \mathrm{O}$ any cancer; history suggestive of carcinoma; valvular heart disease, arrhythmias, chronic inflammatory conditions (IBD, CTD), hypothyroidism, TIA, hsCRP > $10 \mathrm{mg} / \mathrm{L}, \mathrm{CEA}>20$ $\mathrm{ng} / \mathrm{mL}$.

\section{Sample Size}

Sample size is 50 in each group. Sample size was taken conveniently.

\section{Methodology \\ Case Definition}

Patients who presented with c/o acute onset of weakness of limbs are selected clinically and they are confirmed as either ischaemic or haemorrhagic stroke radiologically.

\section{Control Definition}

Controls are selected in medical ward who are admitted for other atherosclerotic diseases and without any weakness of limbs clinically and radiologically.

The stroke patients are subjected to a detailed history, clinical examination and with the help of imaging, classified into ischaemic or haemorrhagic stroke.

The stroke patients are divided into 2 groups (ischaemic and haemorrhagic) of 50 subjects in each group with healthy controls as 3 rd group-

- Group A- Ischaemic Stroke.

- Group B- Haemorrhagic Stroke.

- Group C- Healthy Controls.

The subjects of each group are appropriately matched for age and sex.

Basic investigations with serum CEA and hsCRP are taken within 24 hours onset of symptoms in sample A and B.

The CEA levels of the three groups are then compared.

The CEA levels are compared with hsCRP among the stroke patients.

\section{Reference Values \\ HSCRP Levels. (7)}

- $\quad<1 \mathrm{mg} / \mathrm{L}$ : low risk;

- 1 - $3 \mathrm{mg} / \mathrm{L}:$ moderate risk;

- $3 \mathrm{mg} / \mathrm{L}$ : high risk;
CEA LEVELS(8)

- $\quad<2.5 \mathrm{ng} / \mathrm{mL}$ : normal population;

- $\quad<5 \mathrm{ng} / \mathrm{mL}$ : smokers;

- $\quad>5 \mathrm{ng} / \mathrm{mL}$ : cut-off value in the study.

The normal population is selected from patients attending master health check-up.

\section{Method Used for Estimation of CEA}

ECLIA (Electro-Chemiluminescence Immunoassay)

\section{Method Used for Estimation of hsCRP}

- Durel Turbidimetry.

\begin{tabular}{|c|c|c|}
\hline Groups & Definition of Subjects & Number \\
\hline Infarct Group & Ischaemic stroke patients & 50 \\
\hline $\begin{array}{c}\text { Haemorrhage } \\
\text { Group }\end{array}$ & Haemorrhagic stroke patients & 50 \\
\hline Control Group & Healthy subjects & 50 \\
\hline \multicolumn{2}{|c|}{ Table 1 } \\
\hline
\end{tabular}

\section{Data Analysis}

Descriptive statistics was done for all data and were reported in terms of mean values and percentages. Suitable statistical tests of comparison were done. Continuous variables were analysed with the unpaired ' $t$ ' test. Categorical variables were analysed with the Chi-square test and Fisher Exact test. The accuracy analysis was reported as sensitivity, specificity, PPV, NPV and accuracy. Statistical significance was taken as $\mathrm{p}<$ 0.05. The data was analysed using SPSS version 16 and Microsoft Excel 2007.

\section{RESULTS}

Majority of the infarct group patients belonged to $61-70$ years age class interval $(n=14,28.00 \%)$ with a mean age of 65.84 years. In the haemorrhage group patients, majority belonged to $61-70$ years age class interval $(n=16,32.00 \%)$ with a mean age of 68.36 years. In the control group patients, majority belonged to $71-80$ years class interval $(n=16$, $32.00 \%$ ) with a mean age of 65.16 years. The association between the study groups and age distribution is considered to be not statistically significant, since $\mathrm{p}>0.05$ as per unpaired ' $\mathrm{t}$ ' test.

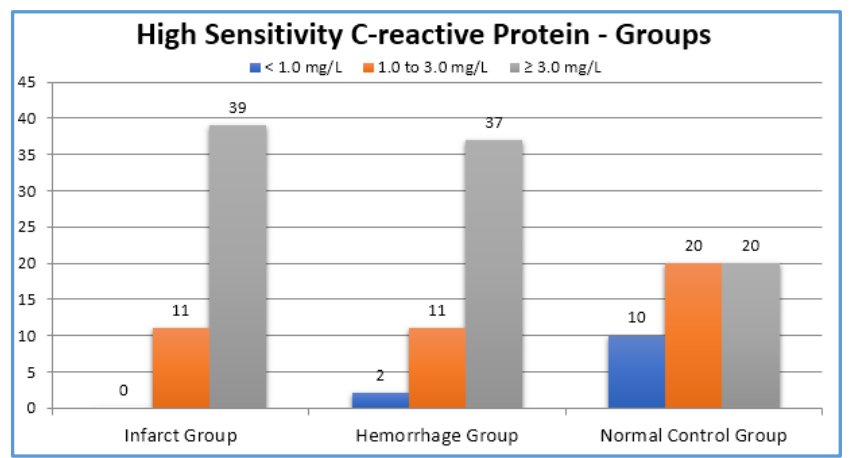

Graph 1. High Sensitivity C-Reactive Protein 


\begin{tabular}{|c|c|c|c|c|c|c|}
\hline $\begin{array}{c}\text { High } \\
\text { Sensitivity C- } \\
\text { Reactive } \\
\text { Protein } \\
\text { Groups }\end{array}$ & $\begin{array}{c}\text { Infarct } \\
\text { Group }\end{array}$ & $\%$ & $\begin{array}{c}\text { Haemor } \\
\text { rhage } \\
\text { Group }\end{array}$ & $\%$ & $\begin{array}{c}\text { Normal } \\
\text { Control } \\
\text { Group }\end{array}$ & $\%$ \\
\hline$<1.0 \mathrm{mg} / \mathrm{L}$ & 0 & 0.00 & 2 & 4.00 & 10 & $\begin{array}{c}20.0 \\
0\end{array}$ \\
\hline 1.0 to $3.0 \mathrm{mg} / \mathrm{L}$ & 11 & 22.00 & 11 & 22.00 & 20 & $\begin{array}{c}40.0 \\
0\end{array}$ \\
\hline$\geq 3.0 \mathrm{mg} / \mathrm{L}$ & 39 & 78.00 & 37 & 74.00 & 20 & $\begin{array}{c}40.0 \\
0\end{array}$ \\
\hline Total & $\mathbf{5 0}$ & $\mathbf{1 0 0}$ & $\mathbf{5 0}$ & $\mathbf{1 0 0}$ & $\mathbf{5 0}$ & $\mathbf{1 0 0}$ \\
\hline & \multicolumn{7}{|c|}{ Table 2 } \\
\hline
\end{tabular}

\begin{tabular}{|c|c|c|c|}
\hline $\begin{array}{c}\text { High Sensitivity C- } \\
\text { Reactive Protein }\end{array}$ & $\begin{array}{c}\text { Infarct } \\
\text { Group }\end{array}$ & $\begin{array}{c}\text { Haemorrhage } \\
\text { Group }\end{array}$ & $\begin{array}{c}\text { Normal } \\
\text { Control } \\
\text { Group }\end{array}$ \\
\hline $\mathrm{N}$ & 50 & 50 & 50 \\
\hline Mean & 5.52 & 4.94 & 3.16 \\
\hline SD & 2.49 & 2.46 & 2.41 \\
\hline \multirow{2}{*}{$\begin{array}{c}\text { P value } \\
\text { Unpaired 't' Test }\end{array}$} & $\begin{array}{c}\text { Infarct Group vs. Normal } \\
\text { Control Group }\end{array}$ & $<0.0001$ \\
\cline { 2 - 4 } & $\begin{array}{c}\text { Haemorrhage Group vs. } \\
\text { Normal Control Group }\end{array}$ & 0.0004 \\
\cline { 2 - 4 } & $\begin{array}{c}\text { Infarct Group vs. } \\
\text { Haemorrhage Group }\end{array}$ & 0.2452 \\
\hline \multicolumn{3}{|c|}{ Table 3 } \\
\hline
\end{tabular}
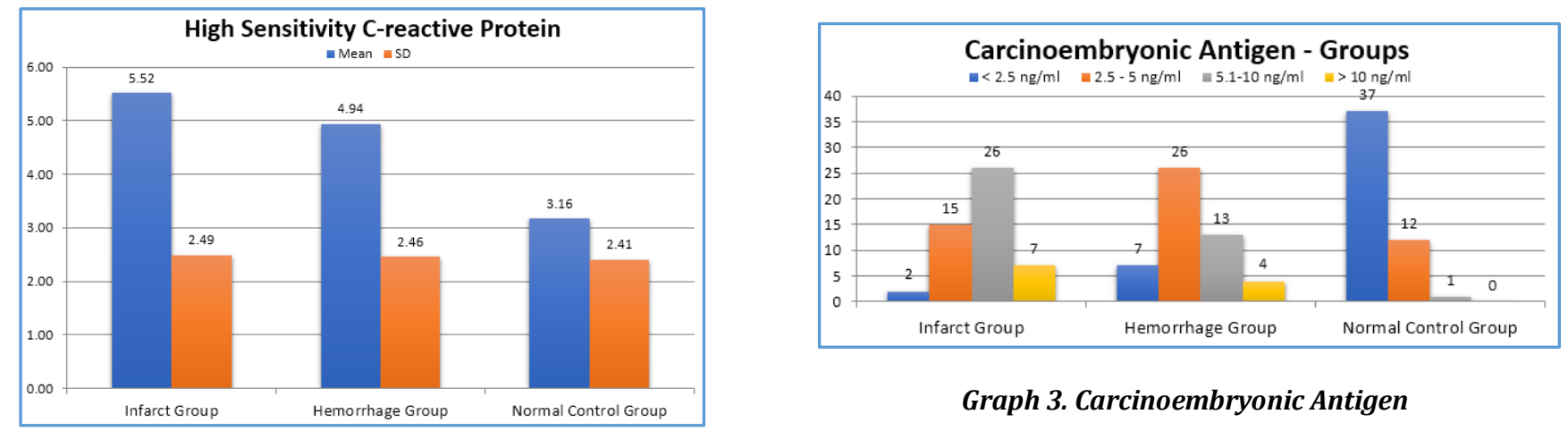

Graph 2. High Sensitivity C-Reactive Protein

Graph 3. Carcinoembryonic Antigen

\begin{tabular}{|c|c|c|c|c|c|c|}
\hline Carcinoembryonic Antigen- Groups & Infarct Group & $\mathbf{\%}$ & Haemorrhage Group & $\mathbf{\%}$ & Normal Control Group & \% \\
\hline$<2.5 \mathrm{ng} / \mathrm{mL}$ & 2 & 4.00 & 7 & 14.00 & 37 & 74.00 \\
\hline $2.5-5 \mathrm{ng} / \mathrm{mL}$ & 15 & 30.00 & 26 & 52.00 & 12 & 24.00 \\
\hline $5.1-10 \mathrm{ng} / \mathrm{mL}$ & 26 & 52.00 & 13 & 26.00 & 1 & 2.00 \\
\hline$>10 \mathrm{ng} / \mathrm{mL}$ & 7 & 14.00 & 4 & 8.00 & 0 & 0.00 \\
\hline Total & $\mathbf{5 0}$ & $\mathbf{1 0 0}$ & $\mathbf{5 0}$ & $\mathbf{1 0 0}$ & $\mathbf{5 0}$ & $\mathbf{1 0 0}$ \\
\hline \multicolumn{7}{|c|}{ Table 4 } \\
\hline
\end{tabular}

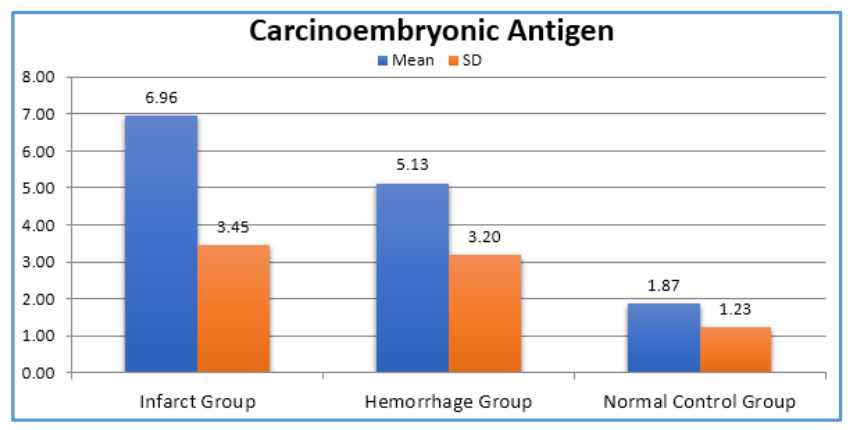

Graph 4. Carcinoembryonic Antigen

\begin{tabular}{|c|c|c|c|}
\hline $\begin{array}{c}\text { Carcinoembryo } \\
\text { nic Antigen }\end{array}$ & $\begin{array}{c}\text { Infarct } \\
\text { Group }\end{array}$ & $\begin{array}{c}\text { Haemorrhage } \\
\text { Group }\end{array}$ & $\begin{array}{c}\text { Normal Control } \\
\text { Group }\end{array}$ \\
\hline $\mathrm{N}$ & 50 & 50 & 50 \\
\hline Mean & 6.96 & 5.13 & 1.87 \\
\hline SD & 3.45 & 3.20 & 1.23 \\
\hline $\begin{array}{c}\text { P value Unpaired } \\
\text { 't' Test }\end{array}$ & $\begin{array}{c}\text { Infarct Group vs. Normal } \\
\text { Control Group }\end{array}$ & $<0.0001$ \\
\hline & $\begin{array}{c}\text { Haemorrhage Group vs. } \\
\text { Normal Control Group }\end{array}$ & $<0.0001$ \\
\hline & $\begin{array}{c}\text { Infarct Group vs. } \\
\text { Haemorrhage Group }\end{array}$ & 0.0071 \\
\hline \multicolumn{3}{|c|}{ Table 5 } \\
\hline
\end{tabular}

\section{DISCUSSION}

High Sensitivity C-Reactive Protein among Stroke Patients-

Majority of the infarct group patients belonged to $\geq 3.0 \mathrm{mg} / \mathrm{L}$ high sensitivity C-reactive protein class interval $(n=39$, $78.00 \%$ ) with a mean value of $5.32 \mathrm{mg} / \mathrm{L}$. In the haemorrhage group patients, majority belonged to $\geq 3.0 \mathrm{mg} / \mathrm{L} \mathrm{high}$ sensitivity C-reactive protein class interval $(n=37,74.00 \%)$ with a mean value of $4.94 \mathrm{mg} / \mathrm{L}$. In the control group patients, majority belonged to $\geq 3.0 \mathrm{mg} / \mathrm{L}$ high sensitivity C-reactive protein class interval $(n=20,40.00 \%)$ with a mean value of $3.16 \mathrm{mg} / \mathrm{L}$. By conventional criteria, the association between the study groups (infarct group vs. control group and haemorrhage group vs. control group) and high sensitivity Creactive protein levels are considered to be statistically significant, since $\mathrm{p}<0.05$ as per unpaired ' $\mathrm{t}$ ' test. The association between the intervention groups (infarct group vs. haemorrhage group) and high sensitivity C-reactive protein levels is considered to be not statistically significant, since $\mathrm{p}>0.05$ as per unpaired ' $\mathrm{t}$ ' test.

\section{Infarct Group vs. Control Group}

The mean high sensitivity C-reactive protein levels were significantly elevated in infarct group compared to control group by a mean difference of $2.36 \mathrm{mg} / \mathrm{L}$ ( $43 \%$ higher). This difference is significant with a p-value of $<0.0001$ as per unpaired ' $\mathrm{t}$ ' test. 


\section{Haemorrhage Group vs. Control Group}

The mean high sensitivity C-reactive protein levels were significantly elevated in haemorrhage group compared to control group by a mean difference of $1.78 \mathrm{mg} / \mathrm{L}(36 \%$ higher). This difference is significant with a p-value of 0.0004 as per unpaired t-test.

In this study, we can safely conclude that infarct and haemorrhage group had significantly higher levels of high sensitivity C-reactive protein levels compared to control group among stroke patients.

In other words, infarct stroke patients had 1.74 times higher sensitivity C-reactive protein levels compared to healthy subjects and haemorrhage stroke patients had 1.56 times higher high sensitivity C-reactive protein levels compared to healthy subjects.

\section{Carcinoembryonic Antigen among Stroke Patients}

Majority of the infarct group patients belonged to 5.1 - 10 $\mathrm{ng} / \mathrm{mL}$ carcinoembryonic antigen class interval $(\mathrm{n}=26$, $52.00 \%$ ) with a mean value of $6.96 \mathrm{ng} / \mathrm{mL}$. In the haemorrhage group patients, majority belonged to 2.5 - 5 $\mathrm{ng} / \mathrm{mL}$ carcinoembryonic antigen class interval $(n=26$, $52.00 \%$ ) with a mean value of $5.13 \mathrm{ng} / \mathrm{mL}$. In the control group patients, majority belonged to $<2.5 \mathrm{ng} / \mathrm{mL}$ carcinoembryonic antigen class interval $(n=37,74.00 \%)$ with a mean value of $5.13 \mathrm{ng} / \mathrm{mL}$. By conventional criteria, the association between the study groups (infarct group vs. control group, haemorrhage group vs. control group and infarct group vs. haemorrhage group) and carcinoembryonic antigen levels is considered to be statistically significant since $\mathrm{p}<0.05$ as per unpaired ' $\mathrm{t}$ ' test.

\section{Infarct Group vs. Control Group}

The mean carcinoembryonic antigen levels were significantly elevated in infarct group compared to control group by a mean difference of $5.09 \mathrm{ng} / \mathrm{mL}$ (73\% higher). This difference is significant with a $\mathrm{p}$-value of $<0.0001$ as per unpaired ' $\mathrm{t}$ ' test.

\section{Haemorrhage Group vs. Control Group}

The mean carcinoembryonic antigen levels were significantly elevated in haemorrhage group compared to control group by a mean difference of $3.26 \mathrm{ng} / \mathrm{mL}(64 \%$ higher $)$. This difference is significant with a $\mathrm{p}$-value of $<0.0001$ as per unpaired ' $\mathrm{t}$ ' test.

\section{Infarct Group vs. Haemorrhage Group}

The mean carcinoembryonic antigen levels were significantly elevated in infarct group compared to haemorrhage group by a mean difference of $1.83 \mathrm{ng} / \mathrm{mL}$ (26\% higher). This difference is significant with a p-value of 0.0071 as per unpaired ' $\mathrm{t}$ ' test.

\begin{tabular}{|c|c|c|}
\hline $\begin{array}{c}\text { Accuracy } \\
\text { Analysis }\end{array}$ & $\begin{array}{c}\text { High Sensitivity C- } \\
\text { Reactive Protein }\end{array}$ & $\begin{array}{c}\text { Carcinoembryonic } \\
\text { Antigen }\end{array}$ \\
\hline Sensitivity & $79.17 \%$ & $50.00 \%$ \\
\hline Specificity & $55.56 \%$ & $98.00 \%$ \\
\hline $\begin{array}{c}\text { Positive Predictive } \\
\text { Value }\end{array}$ & $76.00 \%$ & $98.04 \%$ \\
\hline $\begin{array}{c}\text { Negative Predictive } \\
\text { Value }\end{array}$ & $60.00 \%$ & $49.50 \%$ \\
\hline \multicolumn{2}{|c|}{ Table 6. Accuracy Analysis } \\
\hline \multicolumn{2}{|c}{} \\
\hline \multicolumn{2}{|c|}{} \\
\hline \multicolumn{2}{|c|}{} \\
\hline
\end{tabular}

\section{Sensitivity}

- Sensitivity of high sensitivity C-reactive protein is high, meaning that $79 \%$ of those with hs-CRP > $3 \mathrm{mg} / \mathrm{L}$ will have stroke as diagnosis.

- Sensitivity of carcinoembryonic antigen is moderate, meaning that $50 \%$ of those with CEA $>3 \mathrm{ng} / \mathrm{mL}$ will have stroke as diagnosis.

\section{Specificity}

- Specificity of high sensitivity C-reactive protein is moderate, meaning that $56 \%$ of those with hs-CRP $>3$ $\mathrm{mg} / \mathrm{L}$ will not have stroke as diagnosis.

- Specificity of carcinoembryonic antigen is very high, meaning that $98 \%$ of those with CEA $>3 \mathrm{ng} / \mathrm{mL}$ will not have stroke as diagnosis.

\section{Positive Predictive Value}

- Positive predictive value of high sensitivity C-reactive protein is high, meaning $76 \%$ of individuals diagnosed with stroke will actually have stroke.

- Positive predictive value of carcinoembryonic antigen is very high, meaning $98 \%$ of individuals diagnosed with stroke will actually have stroke.

\section{Negative Predictive Value}

- $\quad$ Negative predictive value is moderate, meaning $60 \%$ of individuals with/without stroke will have hs-CRP $>3$ $\mathrm{mg} / \mathrm{L}$.

- $\quad$ Negative predictive value is moderate, meaning $60 \%$ of individuals with/without stroke will have CEA $>3$ $\mathrm{ng} / \mathrm{mL}$.

\section{Inference}

- The diagnostic effectiveness or diagnostic accuracy in relation to stroke is very high with Carcinoembryonic Antigen compared to high sensitivity C-reactive protein.

\section{CONCLUSION}

The association between the study groups and age distribution is considered to be not statistically significant. The mean serum hsCRP levels in ischaemic stroke and Haemorrhagic stroke and healthy controls were $5.52 \pm 2.49$ $\mathrm{mg} / \mathrm{L}, 4.94 \pm 2.46$ and $3.16 \pm 2.41$.

The hsCRP levels were higher among infarct and haemorrhagic stroke patients than control population.

The mean serum CEA levels in, ischaemic stroke and Haemorrhagic stroke and healthy control were $6.96 \pm 3.95$ $\mathrm{ng} / \mathrm{mL}, 5.13 \pm 3.2 \mathrm{ng} / \mathrm{mL}$ and $1.87 \pm 1.23 \mathrm{ng} / \mathrm{mL}$ respectively.

The CEA levels are higher among stroke patients than normal population. The elevation is more among ischaemic stroke patients than haemorrhagic stroke patients.

Infarct stroke patients had 3.73 times carcinoembryonic antigen levels compared to healthy subjects. Haemorrhage stroke patients had 2.75 times carcinoembryonic antigen levels compared to healthy subjects and infarct stroke patients had 1.36 times carcinoembryonic antigen levels compared to haemorrhage stroke patients.

Elevation of both CEA and hsCRP proves that CEA is associated with a chronic inflammatory state of atherosclerosis.(9) 


\section{The elevation could be because of,(10)}

1. Elevation of CEA in acute stroke as CEA and its family molecules act to minimise the damage to Blood-Brain Barrier.

2. Atherosclerosis, which stimulates the production of CEA.

Although further research is needed, with this result we can say that CEA(11) can be used as-

1. Marker of stroke.

2. Surrogate marker for atherosclerosis.

\section{REFERENCES}

[1] Kasper D, Fauci A, Hauser S. Harrisons principles of internal medicine, 19 th edition.

[2] Ishizaka N, Ishizaka Y, Toda E, et al. Are serum carcinoembryonic antigen levels associated with carotid atherosclerosis in Japanese men? Arterioscler Thromb Vasc Biol 2008;28(1):160-5.

[3] No JI, Yang JY, Hyun HJ, et al. Factors associated with serum levels of carcinoembryonic antigen in healthy non-smokers. Korean J Fam Med 2013;34(6):413-9.

[4] Lee JW, Park KD, Im JA, et al. Serum carcinoembryonic antigen is associated with metabolic syndrome in female Korean non-smokers. Clin Chim Acta 2011;412(7-8):527-30.

[5] Bae U, Shim JY, Lee HR, et al. Serum carcinoembryonic antigen level is associated with arterial stiffness in healthy Korean adult. Clin Chim Acta 2013;415:286-9.
[6] Jauch EC, Saver JL, Adams HP, et al. Guidelines for the early management of patients with acute ischemic stroke: a guideline for healthcare professionals from the American heart association/American stroke association. Stroke 2013;44(3):870-947.

[7] Hemphill JC, Greenberg SM, Anderson CS, et al. Guidelines for the management of spontaneous intracerebral hemorrhage: a guideline for healthcare professionals from the American heart association/American stroke association. Stroke 2015;46(7):2032-60.

[8] Connolly ES, Rabinstein AA, Carhuapoma JR, et al. Guidelines for the management of aneurysmal subarachnoid hemorrhage: a guideline for healthcare professionals from the American heart association/American stroke association. Stroke 2012;43(6):1711-37.

[9] Generalised efficacy of t-PA for acute stroke. Subgroup analysis of NINDS t-PA stroke trial. Stroke 1997;28(11):2119-25.

[10] Stroke Hyperglycemia Insulin Network Effort (SHINE) Trial.

http://clinicaltrials.gov/ct2/show/NCT01369069.

[11] Ducimetiere P, Eschwege E, Papoz L, et al. Relationship of plasma insulin levels to the incidence of myocardial infarction and coronary heart disease mortality in a middle-aged population. Diabetologia 1980;19(3): 205-10. 